\title{
The Education, Social and Women Culture In The Environment of Pesantren Salaf
}

\author{
Yulia Rahman ${ }^{1}$, Zubaidah $^{2}$ \\ \{yuliarahman100787@gmail.com¹, zubaidah@iainbukittinggi.ac.id² ${ }^{2}$, \\ Faculty of Tarbiyah and Teacher Training, Institut Agama Islam Negeri (IAIN) Bukittinggi, Indonesia ${ }^{1,2}$
}

\begin{abstract}
Pesantren (boarding school) of salaf is one of the prides of Islamic educations in Indonesia, because it is the first Islamic education in Indonesia and still survives nowadays by trying to adjust to the changing of times. But in the era of modernization, salaf pesantren often get a negative stigma and an unfavorable image in the public. Starting from the accusation of being a hotbed of terrorism, radical Islamic educational institutions, opposing nationalism, to the accusations as an institution that discredits women in terms of education, social and culture. These issues are quite hurting the feelings of Muslims who put their trust in the salafpesantren as an institution that gives birth toulama (muslim scholars). The aim of this studyis to reveal the role of the salafpesantrenin empowering women in the aspects of educational, social and cultural.At the same time this study is also explaining that the educational, social and cultural model of women in the salaf pesantren can be used as a solution to women's moral degradation and protection of women's rights without reducing and degrading women's dignity and respect. The result of this study indicates that the educational component and the atmosphere of pesantren learning process which includes in-class and outside the classroom take a major role in balancing and aligning understanding of teaching material in classic texts that are considered gender biased.So, the understanding that reaches the students about gender issues is a detailed, complete and comprehensive understanding.
\end{abstract}

Keywords. women education, pesantren tradition, pesantren salaf

\section{Introduction}

The pesantren (Islamic boarding school) is the oldest educational institution in Indonesia with cultural methods and characteristics that are different from others. Nevertheless, pesantren continuesto keep up the education as an effort to empower both men and women. These efforts continue to this very day, where some pesantrens choose to reform their institutions following the modernization, and some others remain consistent with the traditional characteristics of pesantren that are called salaf pesantren.[1]. The existence of salafpesantrentoday is a privilege for the Islamic education because the learning system and the socio-cultural conditions that develop within it are unique and different from other modern educational institutions.[2] One of the highlighted points is the pattern of education and socio-cultural image of women in the salaf pesantren itself. Islam, as a perfect religion, putsthe education for women as important as it is for men. So, the goal of women's education in pesantrensalaf is also to give birth to a generation of Muslim women who are tafaqquh fi al-din;[3]people who are expert in the religious understanding and practicing it in social life, as well as being the womenwith Islamic personality and becoming thecallers for Islam in their community.[4]It also becomes very 
important to know the implementation of the learning towards gender perspective and sociocultural patterns that take place in pesantren. This is related to the stigma says that pesantrensalaf is not paying enough attention to empowering women. For example, the assumptions about gender discrimination that occurs in the leadership and authority inpesantren salaf. In addition, the negative stigma is still directed at the aspects of women's culture in the pesantren salaf, such as the restrictions on the communication between men and women, and the culture of dressing which is considered exaggerated.

In addition to that negative stigma, there is a great hope for the educational and sociocultural conditions of women in the salaf pesantren, it is the emergence of a generation of women muslim scholars who havenoble moral, interactions and culture as a solution to moral degradation among the young generation.

\section{Pesantren Salaf Andempowerment Of Women Education}

\subsection{Pesantren Salaf and The Modernization of Education}

The term ofsalafpesantrenrefers to the educational methods and socio-cultural patterns applied in it. The word pesantrenmeanthe place for santri (student of pesantren) to learn. The word salaf means the past, referring to the use of the term salafrelated to the Islamicteaching method as exemplified by the Prophet Muhammad, the Companions of the Prophet and Kibar al-Tabi'in.[3] In Indonesia, the term salaf is attached to the word pesantren to indicate an oldoriented educational institution consisting of old groups.[5]Another indication is the consistent effort to maintain the tradition of the salaf, from the intellectual content which is related to aspects of the aqeedah, shari'a, morals and sufism.[6]

Historically, pesantren in Indonesia grew and developed following the socio-cultural development of Indonesia. This institution continues to adjust itself to the changing times, until the arrival of western modernization. This situation is quite difficult for pesantren, that tries to maintain a culture of simplicity and traditional. Some ofpesantrensalafs are less able to respond to the changing of the times so rapidly that they ended up to be left behind and conservative. But some others choose to maintain the traditionality and consider it as a feature that must be preserved.[2] This image is in line with Azra's opinion said that traditional pesantrens are institutions that maintain and inherit the continuity of Islamic traditions, both traditions from the aspects of Shari'a and Sufism which cause indications of bid'ah and khurafat practices, or traditions from aspects of Islamic purity that lead to free these institutions from the practice of bid'ah and khurafat.[7]

As an Islamic educational institution that choosesto stand against the mainstream, by preserving tradition rather than following the wave of modernization, the Salaf pesantren is slowly becoming a unique educational institution compared to modern ones. In general, pesantren consists of several components, there are: kyai, santri, masjids, boarding houses and madrassas. These components also become important elements in the Salaf pesantren, as well as having unique conditions and roles in accordance with the traditional institutions.

- Kyai

Kyai, in the pesantren salaf environment, is a major figure in the implementation of education. The influence of a kyai coversmany aspects from learning, leadership, social and cultural conditions and the daily life patterns of pesantren. Every culture, tradition and behavior built by the kyai in the pesantren are derived from the values of the Qur'an, 
Hadith and classical literatures, so that it easily becomes a belief, commitment and loyalty of the students towards the kyai and pesantren.[3]

- Santri (students of pesantren)

The pattern of students' life in the early days of education inpesantren, is moving from place to place to seeking knowledge. This habit is inherited from Javanese culture in the model of adolescent education before adulthood. The teenagers were released from the comfort of family life towards independent living in a pesantren environment.[8] The relationship between santri and pesantren is a new family relationship, where the kyai and teachers are considered as parents who develop the spiritual, intellectual and personal aspects of the santri.

- Masjid

The function of the masjid as a place of learning has taken place since its presence in the life of the Prophet Muhammad. In the next traditions, masjids have a central role in the pesantren environment. Even the existence and development of the majority of pesantrens began with learning at the masjid. In the salaf pesantren, masjid is considered as the most appropriate place to integrate religious ritual activities with classical script learning activities. So, the students usually organize learning after the prayer in congregation.[9]

- Madrasa and boarding house

Madrasa is one of the main learning places in the Salaf pesantren. The education model is oriented towards the transfer of knowledge that takes place in the classroom with a more structured curriculum and methods. Even in most parts of Sumatra, the majority of pesantrens stand on the madrasa education system, not on asrama system like most pesantrens in Java.

The culture of expedition to seek knowledge of the students requires them to live far from homes and families. As a consequence, pesantren must provide lodging facilities for students, known as pondok or asrama (dormitories). A life that is full of simplicity and helps support the character education of the students. In addition, the rules applied in the dormitory are as strong as the rules applied by the pesantren regarding the rules of social relations between santri (male students) and santriwati (female student) which are strict in class, masjid and dormitory.[2]

The general description of the salaf pesantren above indicates the unique educational, social and cultural aspects according to the level of traditionalism that is maintained. At the same time provides positive reasons why salaf pesantren prefers to be more careful towards modernization. Among the salaf pesantren cultures that is unique and special are; first, a strong family culture, where the kyai as the leaders of the pesantren stay very close with their students. The relationship between the kyai and the santri is like the relationship between biological parents and their children, but it still does not violate the norms of politeness. Second, togetherness and the culture of helping each other are more noticeably with the participation of students, kyai and teachers all together to help each other when pesantren experience logistical shortages and daily needs. Each cooperation is carried out sincerely as the form of ibadah Godworshipping. This culture of mutual-help is not only applied insidepesantren life, but also outside of pesantren, with the surrounding community, as the service frompesantren for acceptance and assistance from community.[3] Third, the culture of honesty and simplicity of pesantren which is a reflectedby the kyai, teachers and santri towards understanding of the noble values of Islam in the Qur'an, hadith and classical books. 


\subsection{The Construction of Women's Education in The Literature of Salaf Islamic Pesantren}

The source of education in the Salaf pesantren is originated from Islamic thought which is recorded in classical texts.[10] The focus of learning is Islamic sciences such as, Al-Qur'an, hadith, law (fiqh), Arabic Grammar, suffism, and Arabic Science. In these classic literatures, Islam places women in a portion that is in line with the purpose of its creation, which is to live a harmoniouslife that is paired between men and women. In the view of the Salaf pesantren, the position of women as determined by Allah in the Qur'an is final. So, the duty of Muslims is to understand that behind the difference in roles there are wisdom and secrets that benefit all humans. This understanding is considered different than the understanding of community groups outside the Salaf pesantren environment. So that the view of the Salaf pesantren is considered as traditional thinking that rejects the idea of gender equality.[11] Whereas the opinions that support gender equality are called reformative. Justification of the pesantren's view as a conservative and fundamental opinion towards gender actually ignores the universal values practiced by the pesantren itself.

Empowerment of women in the view of the Qur'an and hadith, as well as the classic literatures studied in traditional pesantren basically tries to create gender equality between men and women in a right understanding. The gender equality in Islam does not mean that women must be the same as men, neitherwomen are to rival or oppose men. However, gender equality means that women and men enjoy the same status, are in the same condition and have the same opportunity to be able to increase their potential.[12] This difference in understanding gender equality is an important basis for reconstructing the image of pesantren towards the empowerment of women thathas been accused as traditional educational institutions dominated by the role of men or patriarchal culture, and discrediting women's dignity. These negative issues are often based on arguments that the classical books which are used as textbooksand teaching materials in the salafpesantren are indicated using words or opinions that position women at a level below men. Among these classic books is the Book of Syarh Uqud al-Lujjayn fi Bayan Huquq al-Zawjain, which was written by Muhammad ibn Umar al-Bantany al-Jawii, (1813-1898 AD). This book is one of the most popular teaching materials among Javanese traditional pesantren. This book contains materials about the obligations of a husband to his wife, the wife to her husband, the primacy of prayer at home for women and the prohibition of men looking at women who are not mahram.[13] The part that is often highlighted as content of gender biases in this book is first, that women's bodies are fitnah (trial) and forbidden to be seen so that it has the potential to bring up women in the public space. Second, marriage women do not have complete control over their own bodies, the body is fully owned by their husbands, so women should not refuse their husbands to have sex. Third, the intelligence and knowledge of men is far above women, which is known as the concept of fadl, so that the obligations of dowry, livelihood and dependents are responsibility of men. This concept has implications for women to obey their husbands who are promised with a great reward.

The next book that is indicated gender bias according to the group so-called reformative is the Book of Syarh Qurrat al-'Uyun by Abu Muhammad al-Tihami Kanun al-Idrisi al-Hasani. This book explains the relationshipbetween husband and wife, from the legal provisions for marriage of men and women to personal matters regarding sexual intercourse between husband and wife, the techniques and ethics, as well as a discussion of parenting and child education at the end of the book.[14]The part that is considered gender biased in this book is first, women are valued in their fertility because of the text of the hadith that encourages marrying fertile 
women. Secondly, the term menstrual taboo, an effort to connect menstruation days with the prohibition of sex intercourse shows the the stereotypes of menstruation as a negative thing even though it is a nature of women. Third, the view that women have many shahwat (lust) that Allah counterbalances by conferring shynessfor women more than it is for men. Fourth, that marriage is a bond for women so that women must submit to men.

Next is aclassic book entitled Risalat al-Mahidh by Masruhan Ihsan written in Arabic pegon (Javanese written in Arabic). Among the issues that are considered to contain gender bias is, the first,the statement about the explanation of the wisdom of menstruation for women, so that women are accustomed to caring for children. This statement is considered as an indication of giving full responsibility to women. Second, there is another wisdom, that menstruation is related to the readiness of women to receive sperm from their husbands after marriage, which is associated with giving dowry, as if the dowry is the price of women. Third, the menstrual blood helps women to reduce their public activities and mobility so that they can control lust more than men, even though women have more dominant shyness.[15]

However, some pesantrens also use the book tittledAdab al-Mu'asharah Bayna al-Zaujaini li Tahsil al-Sa'adat al-Zaujiyyat al-Haqiqiyyati by Akhmad ibn Asmuni. In general, this book states to place husband and wife in the same position and equal to create a sakinah(harmonious) family. However, there are still some discussions which are still considered gender biased by reformers, such as the concept of obedience to husbands.[16]

All the books mentioned above basically convey and explain the teachings of Islam that are purely derived from the Qur'an and hadith. Concepts that are considered gender biased or gender insensitive are Islamic concepts that have been designed by following the life of the Prophet Muhammad and his companions. It's just that the concept must be explained in a comprehensive and holistic way, so that the understanding of Islamic justice views men and women clearly. Because, if we look at the opinions saying that the texts of the classic books are gender biased, it can be seen that the analysis only looks at one side, which is the contents of the book. While other aspects that support the success or failure of learning are not included in making theoretical conclusions, such as the atmosphere of learning and other educational components.

One of the examples is the discussion on the limits of women's aurat(parts of body that must be covered) which has implications for restrictions on women's mobility in public spaces. What should be highlighted is that the main objective of this concept is an Islamic effort to protect women from moral degradation, not to be used as an argument to ban women's activities in the public space. At the beginning, Muslim societies that were pro to Western modernization argued that Muslim backwardness was due to the restrictions on female aurat. But in the following decades, it was proven thatthe fall of women's honor was due to the freedom of women to be in public space with uncovered aurat. This condition continues until sexual harassment occurs to women openly and is difficult to contain.[17]

The assumption of gender bias regarding the husband's total ownership of his wife's body after the marriage should not only be seen from the text of the classic book studied at the Salaf pesantren. The method of learning and the atmosphere of learning in the Salaf pesantren environment will significantly influence the students' views of the concept about this issue. The ownership does not mean absolute and total towards female body. But the husband's ownership of his wife is based on ibadah (worshiping God) to complement each other as a couple. So, the obligation to obey does not apply if it is a disobedience to God. The importance of husband's permission for the wife to leave the house and to give charity contains wisdom about the concept of husband's leadership as the leader of the household, is solely to maintain harmony. Likewise, the husband's right to his wife's body which cannot be seen as an attempt to lower the 
degree of women. However, ownership must be accompanied by the husband's obligation to love his wife, so that the husband's rights can only be obtained without pressure or domestic violence.

Likewise, the concept of fadhl that is male strength over female's, the advice to marry a walud(fertile) woman and the hadiths that mention women's lust and mensturation relatedto their duties as housewives. All concepts are conveyed in comprehensive learning process with methods and additional explanations from the kyai and teachers. So, it is not fair if the justification of gender bias towards pesantren is only based on the analysis of the classical text. In fact, the culture of salaf pesantren is actually the culture of protection for women and the supporting the important role of women as mothers and housewives. In contrast to the modern world, in the environment of the Salaf pesantren, housewives take a placethat is very respectable and proud, as a pillar of religion and the country,to give birth to generations of Muslims whose orientation is insan kamil. In this case, the educational component besides the learning material plays an important role in the success of students' understanding of the learning material. The general objective of learning in salaf pesantren is to guide students to have a true Muslim personality and to become a preacher, to practice their knowledge in the community.[18] All knowledge and actions taught by pesantren is based on the tauhid (righteous belief in monotheism). According to learning objectives, each learning material must be in the framework oftauhid hanif (true of belief). This means that all materials related to women are understood and taught on the basis of the belief that God compiles all the rules for the good of humanity. And for the students, with a strong belief of tauhid rububiyyah,they realize that the text of the classic booksdoes not indicate that Islamic teachings reduce the role and position of women. Therefore, the texts of classical books can not be understood from what is written, then considered not to be gender sensitive.

The curriculum, methods and educational media are arranged in stages to facilitate students in understanding the context of the textbooks. The first stage is presenting global picture by delivering basic material of aqidahand general knowledge about al-Qur'an and hadith. The second stage is al-syarh wa al-bayan, delivering teaching materials along with a review of various related views.The last stage is takhallush by delivering the material thoroughly and in detail. The learning methods in traditional pesantren are not entirely bad and backward. The bandongan, sorogan and wetonan methods have unique learning standard. Bandongan, for instance, encourages students to study more independently, students listen and participate in reading the book while making small notes on the papers they read to be used as a guide in further study. Santri also had the opportunity to ask questions or further explanation. Sorogan and Watonan are educational methods which are not only carried out collectively, together with Asatidz and other students. In the sorogan and wetonan, the relationship between asatidz and santri is more prominent, so that it has a positive impact on the success of understanding the study.[19]Teaching processthat is considered gender biased through this traditional method can be done more freely, openly and detail. Asatidz can affirm each lesson and wisdom from the theories relatedto women.

\subsection{The Socio-Cultural Life of Women in the SalafPesantren}

The opinion that accuses the salafpesantrenwhen it comes to women's education and socio-cultural can be disputed by looking at the socio-cultural living of women in the environment of salafpesantren. Islamic boarding schools are seen as social institutions that are created, run and developed by men. While women in the educational and social system of pesantren are considered as subordinateand have a social status below men. The authority of a 
Kyai as the leader of a pesantren seems to be a conqueror for his subordinates.[20] However, the patriarchal culture is only seen in the leadership status of the pesantren and the authority as the pesantren owner. Besides that, there are still many socio-cultural aspects of pesantren that do not place women as subordinates. The socio-cultural life of the salafpesantren is also important in education. Pesantren education is the best education because it organizes full day school.[21] In relation to women's education, salafpesantren have a socio-cultural life that supports women's empowerment.

- $\quad$ The Exemplary, The life of the salafpesantren is taughtby example which come from the kyai as leaders, asatidz as educators and senior students. Exemplary can also come from the kyai's family, guards and all residents in pesantren. Although leadership is held bya man, but the exemplary leader with his subordinates teaches the students about the justice of the Islamic view toward women. The glory and honor of women are the responsibility of men. This can be seen from the separation between the man and woman classes and their strict regulation of social ethics. The same example can be shown by the kyai and asatidz(teachers) in their family life which can be seen directly by the students, because their residencesare still within the boarding school environment. Their character and socio-cultural patterns indirectly become additional explanations for materials related to the family and the relationship between the rights and obligations of husband and wife that are considered gender biased.

- Exercise and Habituation, Training and habituation are the dominant methods in the pesantren environment. Each learning material in the classroom ispracticed and exercised by the students in the dormitory and pesantren. For instance, practice and habituation of multi-lingual communication, fashion models and ethics of interaction. In the context of gender, the students areindirectly trained and accustomed to protecting women, to lower gaze for respecting them, which is considered by the reformative group as an act of humiliating women because their body is considered as fitnah (trial). This is the opposite of Islamic teachings that ordered men to lower their gaze to honor women.

\subsection{Socio-Cultural Education through 'Ibrah and Mau'idzah Hasanah}

'Ibrah is a psychological condition where humans try to find the essence of an event he witnessed and experienced to then decide with reason so that the decision affects the heart to submit to it and produces behavior that is consistent with it.[22] With this cultural education of 'ibrah, women in the salaf pesantren have great chance to understand the wisdom of Islamic teachings about the limits of women's aurat, and the importance of woman's roles in the family, both as wife and mother. So that they realize that those duties are noble tasks that give benefits in the long term and in the end, it will determine whether good or not the morality of a society. Mau'idzhah is a remembrance and advice for goodness and truth in a way that touches the heart and contains motivation to practice it.[23] This method has a great influence on male and female students in understanding how Islam sees the socio-cultural status of women. This method utilizes students' closeness to the leaders and people in pesantren. Closeness is considered as a form of family and ukhuwahIslamiyah(Islamic brotherhood) values, which can not be easily found in other modern educational institutions.

\subsection{Socio-Cultural Education through the Methods ofTarghib and Tahdzib}

Targhib is a promise and motivation that directs someone to do good. Whereas tahdzib is a threat that encourages someone to stop evil.[22] The distinction of targhib and tahdzib in the 
pesantren environment is not merely to gain material benefits and avoid losses. But that promise and threat is rooted in obedience and devotion to Allah, by seeking His good pleasure and avoiding His anger. Women's socio-cultural education through this method encourages them to understand that Islamic rules over women are an expression of God's justice and harmony in regulating human life. These teachings can not be measured by looking at the advantages and disadvantages of the material alone, but more than that, all of this is to seek the ease of Allah.

\section{Conclusion}

Salaf Islamic Boarding School is entitled as the first educational model in Indonesia, and theinitial reference for modern education. The design of education which is based on Islamic teachings makes the salafpesantren an educational institution and the empowerment of women, both from social and cultural aspects. The women's education in salaf pesantren cannot only be assessed from the content of teaching material in the classical books studied, because it can lead to a negative view of the existence of gender bias. However, there are other factors that indicate that the salafpesantren applies gender equitable education. These factors include the education component and the atmosphere of learning in pesantren. The education component that supports fair education for women is a curriculum developed in tadarruj (step by step), an educational method that is oriented towards psychological relationship between educators and students and among students themselves. Whereas the atmosphere of learning that indicates the views of the salafpesantren in honoring the position of women can be seen from the daily life of the pesantren as part of education. That includes exemplary, training and habituation outside the classroom, pesantren socio-cultural education methods through 'ibrah, mau'idzhah hasanah, and targhib and tahdzib. Strengthening the learning aspects above must be a concern of various parties, both internal and external of pesantren. So, there is no longer a negative view of the model of learning of the salaf pesantren which is the pride of Islamic education in Indonesia.

\section{References}

[1] I. Syafe'i, "Pondok Pesantren: Lembaga Pendidikan Pembentukan Karakter," Issn 20869118, vol. 8, pp. 85-103, 2017.

[2] H. Hasyim, "Transformasi Pendidikan Islam (Konteks Pendidikan Pondok Pesantren )," J. Pendidik. Agama Islam -Ta'lim, vol. 13, no. 1, pp. 57-77, 2015.

[3] M. S. Hanafi, "Budaya Pesantren Salafi,” J. Chem. Inf. Model., vol. 53, no. 9, pp. 1689-1699, 2013.

[4] H. Indra, Pendidikan Pesantren Dan Perkembangan Sosial Kemasyarakatan. 2018.

[5] M. R. Woodward, Islam Jawa: Kesalehan Normatif Versus Kebatinan. Yogyakarta: LKiS, 2012.

[6] A. Malik, "Jaringan Intelektual dan Ideologi Pesantren Salafi Jihadi: Studi Pada Daerah 'Zona Merah' Terorisme di Bima,” TA’ ALLUM J. Pendidik. Islam, vol. 06, no. November, pp. 223-240, 2018.

[7] A. Azra, Pendidikan Islam: Tardisi dan Modernisasi Menuju Millenium Baru. Jakarta: Logos, 1999.

[8] D. . Rahardjo, “The Kyai, the Pesantren and the Village,” Indones. J. Soc. Econ. Aff., vol. 1, p. 34, 1975.

[9] M. Ziemek, Pesantren dalam Perubahan Sosial. Jakarta: P3M, 1986.

[10] Z. Dhofier, The Pesantren Tradition: The Role of Kyai in the Maintenance of Traditional Islam in 
Java. Arizona: Arizona State University, 1999

[11] W. Nuroniyah, "Feminisme dalam Pesantren: Narasi Pemberdayaan Perempuan di Pondok Pesantren Buntet Cirebon," Holistik, vol. 14, no. 01, pp. 151-174, 2013.

[12] D. Ratnasari, "Pemberdayaan Perempuan dalam Pendidikan Pesantren," 'Anil Islam J. Kebud. dan Ilmu Keislam., vol. 9, no. 1, pp. 122-147, 2016.

[13] M. ibn U. Al-Bantani, Syarh 'Uqud al-Lujjain fi Bayan Huquq al-Zaujain. Surabaya: Dar al-'Ilmi.

[14] A. M. al-T. K. al-I. Al-Hasani, Qurrat al-'Uyun bi Syarh Nadzm ibn Yamin fi al-Nikah al-Syar'i wa Adabihi. Surabaya: Al-Hidayah.

[15] M. Ihsan, Risalat al-Mahidh. T.tp: t.p.

[16] E. Marhumah, Konstruksi Sosial Gender di Pesantren (Studi Kuasa Kiai atas Wacana Perempuan. Yogyakarta: LKiS, 2011.

[17] M. F. Hidayanto, “Aurat Wanita dalam Aturan Hukum,” Al-Mawarid, vol. 5, p. 81, 1996.

[18] Mansur, Moralitas Pesantren. Yogyakarta: Safiria Insani Press, 2004.

[19] S. A'dlom, "Sistem Pendidikan Pesantren Tradisional Dalam Era Modern," J. Pusaka, vol. 3, no. 1, pp. 38-48, 2015.

[20] A. Hannan, "Gender dan Fenomena Patriarki Dalam Sosial Pendidikan Pesantren (Studi Tentang Hegemeoni Kiai Pesantren Terhadap Sosial Pendidikan Bias Gender)," Semin. Nas. Gend. dan Budaya Madura III, no. Madura: Perempuan, Budaya \& Perubahan, pp. 229-234, 2016.

[21] Z. Mukhdar, K.H Ali Maksum: Perjuangan dan Pemikiiiirannya. Yogyakarta: LKiS, 1999.

[22] A. R. Al-Nahlawi, Prinsip-prinsip dan Metode Pendidikan Islam. Bandung: Diponegoro, 1992.

[23] R. Ridha, Tafsir al-Manar. Mesir: Maktabah al-Qahirah. 